\title{
Tropospheric methane in the tropics - first year from IASI hyperspectral infrared observations
}

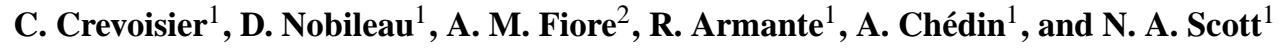 \\ ${ }^{1}$ Laboratoire de Météorologie Dynamique/CNRS/IPSL, Ecole Polytechnique, Palaiseau, France \\ ${ }^{2}$ Geophysical Fluid Dynamics Laboratory/NOAA, Princeton, New Jersey, USA
}

Received: 21 January 2009 - Published in Atmos. Chem. Phys. Discuss.: 12 March 2009

Revised: 17 July 2009 - Accepted: 21 August 2009 - Published: 2 September 2009

\begin{abstract}
Simultaneous observations from the Infrared Atmospheric Sounding Interferometer (IASI) and from the Advanced Microwave Sounding Unit (AMSU), launched together onboard the European MetOp platform in October 2006, are used to retrieve a mid-to-upper tropospheric content of methane $\left(\mathrm{CH}_{4}\right)$ in clear-sky conditions, in the tropics, over sea, for the first 16 months of operation of MetOp (July 2007-October 2008). With its high spectral resolution, IASI provides nine channels in the $7.7 \mu \mathrm{m}$ band highly sensitive to $\mathrm{CH}_{4}$ with reduced sensitivities to other atmospheric variables. These channels, sensitive to both $\mathrm{CH}_{4}$ and temperature, are used in conjunction with AMSU channels, only sensitive to temperature, to decorrelate both signals through a non-linear inference scheme based on neural networks. A key point of this approach is that no use is made of prior information in terms of methane seasonality, trend, or geographical patterns. The precision of the retrieval is estimated to be about $16 \mathrm{ppbv}(\sim 0.9 \%)$. Features of the retrieved methane space-time distribution include: (1) a strong seasonal cycle of $30 \mathrm{ppbv}$ in the northern tropics with a maximum in January-March and a minimum in July-September, and a flat seasonal cycle in the southern tropics, in agreement with in-situ measurements; (2) a latitudinal decrease of $30 \mathrm{ppbv}$ from $20^{\circ} \mathrm{N}$ to $20^{\circ} \mathrm{S}$, in boreal spring and summer, lower than what is observed at the surface but in excellent agreement with tropospheric aircraft measurements; (3) geographical patterns in good agreement with simulations from the atmospheric transport and chemistry model MOZART-2, but with a higher variability and a higher concentration in boreal winter; (4) signatures of $\mathrm{CH}_{4}$ emissions transported to the middle troposphere such as a large plume of elevated tropospheric methane south of the Asian continent, which might be due to Asian emissions from rice pad-
\end{abstract}

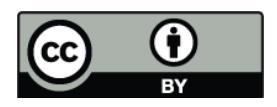

Correspondence to: C. Crevoisier (cyril.crevoisier@1md.polytechnique.fr) dies uplifted by deep convection during the monsoon period and then transported towards Indonesia. In addition to bringing a greatly improved view of methane distribution, these results from IASI should provide a means to observe and understand atmospheric transport pathways of methane from the surface to the upper troposphere.

\section{Introduction}

Knowledge of today's methane $\left(\mathrm{CH}_{4}\right)$ sources and sinks, their spatial distribution and their variability in time is essential for predicting the future $\mathrm{CH}_{4}$ atmospheric concentration levels, which is second only to carbon dioxide $\left(\mathrm{CO}_{2}\right)$ as an important human-caused greenhouse gas (IPCC, 2007). In particular, the tropics are crucial to global budgets of methane. Tropical wetlands are believed to be a considerable $\mathrm{CH}_{4}$ source (e.g., Cicerone and Oremland, 1988; Prentice et al., 2001; Mikaloff-Fletcher et al., 2004a; Chen and Prinn, 2006; Bousquet et al., 2006), as well as emissions from rice paddies (Huang et al., 2004) and termites. Tropical deforestation is also associated with considerable emissions of $\mathrm{CH}_{4}$, since the bulk of this deforestation is accomplished through fires. The tropics also play a major role in $\mathrm{CH}_{4}$ and carbon monoxide $(\mathrm{CO})$ chemistry, due to the considerable photochemical production of $\mathrm{OH}$ in these regions (e.g., Spivakovsky et al., 2000), which is the main sink of methane by globally removing about $85 \%$ of methane molecules emitted to the atmosphere (e.g., Logan et al., 1981). However, the exact location, intensity and nature of methane sources and sinks are still not fully elucidated.

Atmospheric inversions have been widely used to estimate regional fluxes of $\mathrm{CH}_{4}$ (Houweling et al., 1999; MikaloffFletcher et al., 2004b; Chen and Prinn, 2006; Bousquet et al., 2006; Bergamaschi et al., 2007). In these approaches, regional fluxes of a given gas to the atmosphere are estimated through the comparison of atmospheric gas concentration

Published by Copernicus Publications on behalf of the European Geosciences Union. 
observations with atmospheric transport model simulations that describe how surface fluxes influence gas concentrations. Atmospheric inversions have historically relied primarily on in-situ surface observations. This technique generally has the greatest uncertainties in the tropics, because there are very few in-situ observations that effectively constrain these regions (e.g., Rayner and O'Brien, 2001). Furthermore, vigorous tropical convection rapidly transports methane to high altitudes, so that these fluxes are not easily detected by surface observations. By densely sampling the atmosphere in time and space, satellite measurements of the distribution of global atmospheric $\mathrm{CH}_{4}$ concentration may meaningfully fill this gap in scale as suggested by several studies (Bergamaschi et al., 2007; Meirink et al., 2008; Frankenberg et al., 2008).

In recent years, several instruments have given access to information on the distribution of methane in various parts of the atmosphere. Measurements made by the Halogen Occultation Experiment (HALOE) on the Upper Atmosphere Research Satellite (UARS) (Schoeberl et al., 1995; Park et al., 1996; Randel et al., 1998) have provided information on methane in the stratosphere. Tropospheric columns of methane have been retrieved from observations made in the infrared by the Interferometric Monitor for Greenhouse Gases (IMG) flying on board the Japanese Advanced Earth Observing Satellite (ADEOS) (Clerbaux et al., 2003), but because of satellite failure, only a few operation periods of successive days are available over 10 months. Total columns of methane have also been retrieved, mostly over land, from near infrared observations by the Scanning Imaging Absorption spectroMeter for Atmospheric CHartographY (SCIAMACHY) instrument on board the European Space Agency's environmental research satellite (ENVISAT) (Frankenberg et al., 2005, 2006, 2008; Buchwitz et al., 2006). More recently, global $\mathrm{CH}_{4}$ distribution, mostly representative of the middle to upper troposphere, have been retrieved using observations from the Atmospheric Infrared Sounder (AIRS) on the EOS/Aqua platform (Xiong et al., 2008).

With its 8461 channels covering most of the infrared spectrum at a high spectral resolution, the Infrared Atmospheric Sounding Interferometer (IASI) launched onboard the European MetOp platform in October 2006, gives the opportunity to use several channels specifically sensitive to $\mathrm{CH}_{4}$, and to improve our presently limited knowledge of its tropospheric distribution. $\mathrm{CH}_{4}$ infrared measurements being sensitive to both temperature and $\mathrm{CH}_{4}$ variations, an independent information on temperature is needed to allow separating these two effects. Also flying onboard MetOp, the Advanced Microwave Sounding Unit (AMSU) provides microwave observations only sensitive to temperature that can be used to reach this goal. This study is focused on the tropical belt $\left(20^{\circ} \mathrm{N}: 20^{\circ} \mathrm{S}\right)$ where higher-quality retrievals are expected compared to the extratropics because of the low variability of the temperature profiles.
The goals of this paper are to present the first sixteen months of methane retrieved from MetOp IASI/AMSU observations. Section 2 describes data and modeling tools used in the retrieval process. Section 3 presents the selection of IASI channels based on their sensitivity to methane and other atmospheric variables, along with the non-linear inference scheme used to retrieve a tropospheric integrated content of $\mathrm{CH}_{4}$. Section 4 describes the retrievals in terms of seasonal cycle, latitudinal variations and geographical distribution, which are analyzed using in-situ data (surface and airborne measurements) and simulations from an atmospheric chemistry and transport model. Section 5 gives the conclusion.

\section{Data and modeling tools}

\subsection{Satellite data: IASI and AMSU}

The Infrared Atmospheric Sounding Interferometer (IASI) developed by the Centre National d'Etudes Spatiales (CNES) in collaboration with the European Organisation for the Exploitation of Meteorological Satellites (EUMETSAT) is a Fourier Transform Spectrometer based on a Michelson Interferometer coupled to an integrated imaging system that measures infrared radiation emitted from the Earth. IASI provides 8461 spectral samples, aligned in three bands between $645.00 \mathrm{~cm}^{-1}$ and $2760.00 \mathrm{~cm}^{-1}(15.5 \mu \mathrm{m}$ and $3.63 \mu \mathrm{m})$, with a spectral resolution of $0.50 \mathrm{~cm}^{-1}$ after apodisation ('Level1c' spectra). The spectral sampling interval is $0.25 \mathrm{~cm}^{-1}$. IASI is an across track scanning system with scan range of $\pm 48.3^{\circ}$, symmetrically with respect to the nadir direction. A nominal scan line covers 30 scan positions towards the Earth. The instantaneous field of view (IFOV) has a ground resolution of $12 \mathrm{~km}$ at nadir.

Also flying onboard MetOp, the Advanced Microwave Sounding Unit (AMSU) is a cross-track scanning total-power radiometer with 15 channels that measure scene radiance in the microwave spectrum from 23.8 to $89.0 \mathrm{GHz}$. The AMSU instrument has an IFOV of $48 \mathrm{~km}$ at nadir, with scan range of $\pm 48.3^{\circ}$ from nadir with a total of 30 Earth fields-of-view per scan line. The swath width is approximately $2000 \mathrm{~km}$.

IASI Level1c and AMSU Level1b data are available since July 2007. IASI Level2 data, produced at EUMETSAT, are available for temperature and water vapor since October 2007. Temperature and humidity profiles are given on a 90 level grid. Their estimated accuracies are respectively $1 \mathrm{~K}$ and $10 \%$ (Pougatchev et al., 2009). Both Level1c and Level2 data are routinely archived at the Laboratoire de Météorologie Dynamique (LMD) via the Centre for Atmospheric Chemistry Products and Services 'Ether' website (http://ether.ipsl.jussieu.fr/), through EUMETCast, the Broadcast System for Environmental Data of EUMETSAT. 


\subsection{Radiative models and data: 4A and TIGR}

Infrared radiative simulations used in this study are performed using the fast line-by-line 4A (Automatized Atmospheric Absorption Atlas) model (Scott and Chédin, 1981; http://ara.lmd.polytechnique.fr/; http://www.noveltis. fr/4AOP/). Co-developed by LMD and NOVELTIS with the support of CNES, 4A is the reference radiative transfer model for the CNES/EUMETSAT IASI Level $1 \mathrm{Cal} / \mathrm{Val}$ and operational processing. Here, it uses spectroscopy from the regularly updated GEISA (Gestion et Etude des Informations Spectroscopiques Atmosphériques: Management and Study of Spectroscopic Information) spectral line data cata$\log$ (Jacquinet-Husson et al., 2008).

Our study is based on a statistically representative description of the atmosphere from the Thermodynamic Initial Guess Retrieval (TIGR) database (Chédin et al., 1985; Chevallier et al., 1998), with associated radiative information. Use is made of the latest version of TIGR which comprises 7490 tropical atmospheric situations (4425 over sea, the remaining over land), each of them described by its profiles of temperature, water vapour and ozone. $\mathrm{CO}_{2}, \mathrm{CH}_{4}$, $\mathrm{CO}$ and $\mathrm{N}_{2} \mathrm{O}$ reference concentrations are assumed constant along the vertical at $372 \mathrm{ppmv}, 1860 \mathrm{ppbv}, 100 \mathrm{ppbv}$ and $324 \mathrm{ppbv}$, respectively. For all TIGR atmospheric situations, for all scan angles, and for the 8461 IASI channels (about $10^{9}$ cases all together), clear-sky brightness temperatures (BT), transmittances and Jacobians (partial derivative of the channel BT with respect to a layer physical variable such as a gas mixing ratio, a temperature or the emissivity) are computed using 4A. The 15 AMSU BT are computed using the in house STRANSAC microwave forward model.

The noise due to the instrument is also computed using the following equation

$$
N E \Delta T\left(\nu, T_{B}(\nu)\right)=N E \Delta T\left(\nu, T_{\mathrm{ref}}\right) \frac{\frac{\partial B}{\partial T}\left(\nu, T_{\mathrm{ref}}\right)}{\frac{\partial B}{\partial T}\left(\nu, T_{B}(\nu)\right)}
$$

where $N E \Delta T$ is the equivalent noise temperature taken at the brightness temperature $T_{B}$, of the channel located at frequency $\nu$, and $B$ is the radiance. The reference noise corresponding to a reference temperature $T_{\text {ref }}$ of $280 \mathrm{~K}$ is taken from the in-flight noise measurement (CNES, personal communication).

\subsection{Atmospheric chemical and transport simulations: MOZART-2}

For analyzing the IASI retrievals, use is made of $\mathrm{CH}_{4}$ mixing ratio fields simulated by the atmospheric chemistry and transport model MOZART-2 (Horowitz et al., 2003), driven by National Center for Environmental Prediction (NCEP) reanalysis with a $1.9^{\circ} \times 1.9^{\circ}$ spatial resolution and $29 \mathrm{lev}$ els in the vertical. For all species except $\mathrm{CH}_{4}$, EDGAR v2.0 emissions are used as surface boundary conditions
(Horowitz et al., 2003). $\mathrm{CH}_{4}$ anthropogenic emissions are interpolated using EDGAR 3.2 anthropogenic emission estimates for 1990 and 1995 (Olivier and Berdowski, 2001), and 'FAST-TRACK' for 2000 (Olivier et al., 2005). As described in Fiore et al. (2006) (their "ANTHRO+BIO" simulation), emissions for intermediate years are obtained by linear interpolation, with emissions for 2001-2004 held at 2000 values. Wetland $\mathrm{CH}_{4}$ emissions are from Wang et al. (2004), based on the spatial and seasonal distributions of Matthews and Fung (1987).

\section{Methane retrieval method}

\subsection{Channel selection: Sensitivity study of IASI chan- nels}

IASI presents 8461 channels covering most of the infrared spectrum. Only a hundred of them are sensitive to methane. They are either located in band $\nu_{4}$ of methane, around $7.7 \mu \mathrm{m}$ $\left(1306 \mathrm{~cm}^{-1}\right)$, or in band $\nu_{3}$, around $3.8 \mu \mathrm{m}\left(2630 \mathrm{~cm}^{-1}\right)$, and present various sensitivities to methane and other atmospheric or surface components. The first problem arising in the retrieval method is thus the selection of a set of channels presenting the best properties regarding the retrieval of methane. As described in Crevoisier et al. (2003), three criteria must be used to reach this goal: (1) the sensitivity of the channels to atmospheric $\mathrm{CH}_{4}$ changes; (2) the sensitivity of the channels to other gases or thermodynamic variables of the atmosphere; (3) the part of the atmosphere to which the channels are sensitive to $\mathrm{CH}_{4}$ variations.

The sensitivity to methane variations of channels located in the $3.8 \mu \mathrm{m}$ band is much lower than that of channels located in the $7.7 \mu \mathrm{m}$ band due to weaker absorption lines: they won't be considered here. In the $7.7 \mu \mathrm{m}$ band, channels are sensitive to water vapor $\left(\mathrm{H}_{2} \mathrm{O}\right)$, nitrous oxide $\left(\mathrm{N}_{2} \mathrm{O}\right)$ and surface characteristics. The corresponding variations, averaged over the TIGR tropical atmospheric situations, are plotted in Fig. 1 in terms of variation of the measured brightness temperature for a variation of $1 \mathrm{~K}$ for atmospheric temperature, $10 \%$ for $\mathrm{CH}_{4}, 20 \%$ for $\mathrm{H}_{2} \mathrm{O}, 2 \%$ for $\mathrm{N}_{2} \mathrm{O}$ and 0.01 for surface emissivity. The instrument noise is also plotted in Fig. 1.

The main interference, as far as $\mathrm{CH}_{4}$ is concerned, comes from $\mathrm{H}_{2} \mathrm{O}$, which dominates the infrared spectrum in the methane absorption bands. Since water vapor variability is quite high, especially in the tropics, and knowledge of its tropospheric distribution still limited, separating the $\mathrm{CH}_{4}$ signal from water vapor is quite challenging and precludes using most of the channels. Only a few successive channels located in the 1301-1305 $\mathrm{cm}^{-1}$ interval (shown with an arrow in Fig. 1) present a low-enough sensitivity to water vapor to be used to retrieve methane. The nine selected channels are given in Table 1, along with their sensitivities and altitude of the maximum of their associated $\mathrm{CH}_{4}$ Jacobians. They are not sensitive to nitrous oxide or surface characteristics. 


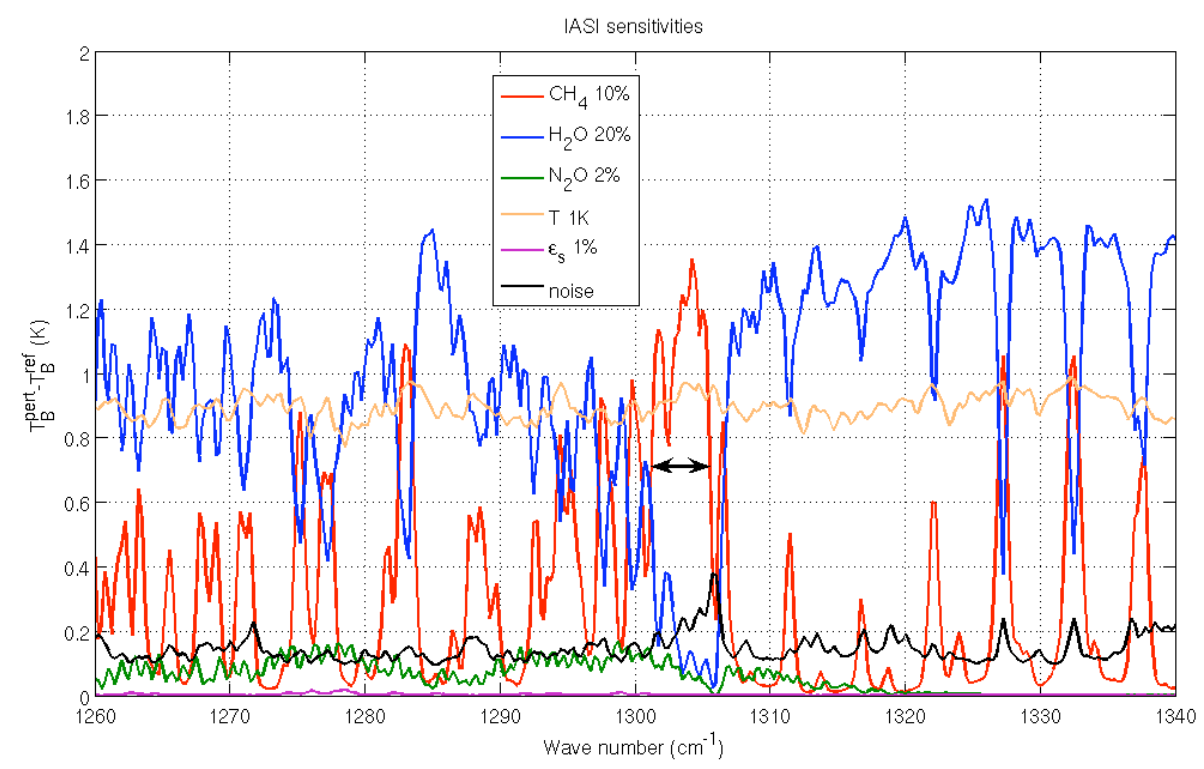

Fig. 1. Sensitivities of IASI channels located in the $7.7 \mu \mathrm{m}$ band to variations of methane (10\%), water vapor (20\%), nitrous oxide (2\%), atmospheric temperature $(1 \mathrm{~K})$, surface emissivity $(0.01)$, and instrument noise computed at the brightness temperature. Average over the 4425 TIGR tropical atmospheric situations. Arrows denote the spectral range where channels selected to retrieve methane are located.

The spectral range where these channels are located can be affected by two phenomena: line mixing and water continuum. Both have been taken into account in the simulations. The line-mixing parameterisation is taken from Niro et al. (2005). The sensitivity to water continuum may be derived by comparing simulations performed with and without inclusion of the continuum. For the nine selected channels, this results in a signal of $0.01 \mathrm{~K}$ on average over the tropical TIGR simulations with an associated standard deviation of $0.05 \mathrm{~K}$. Therefore, the impact of a change in the continuum on the retrievals remains low. Moreover, the radiative biases described in Sect. 3.3 take into account any imprecision in the simulation of the continuum and line-mixing. For the sake of comparison, only 4 similar AIRS channels, two of them with a slight sensitivity to surface characteristics, are available in the same region (Crevoisier et al., 2003).

Methane Jacobians of the 9 channels are plotted in Fig. 2a. Corresponding temperature and $\mathrm{H}_{2} \mathrm{O}$ Jacobians are shown in Fig. $2 b$ and c, respectively. Infrared channels are not sensitive to variations of methane in two parts of the atmosphere: the lower troposphere (roughly below $500 \mathrm{hPa}$ ) and the tropopause (Crevoisier et al., 2003). This lack of sensitivity to the lower part of the atmosphere is a well-known feature of emission based sounding instruments and occurs because of the lack of temperature contrast between the surface and the boundary layer. In the $7.7 \mu \mathrm{m}$ band, the Jacobians have very similar shapes and all peak around $260 \mathrm{hPa}$. Hence IASI only allows the retrieval of a mid-to-upper tropospheric integrated content of methane. The use of the $v_{3}$ absorption band may potentially bring some information on the lower atmosphere under very specific conditions such as high reflected solar radiation (Razavi et al., 2009). The use of the $v_{4}$ band only, although yielding retrievals in the middle troposphere only, allows the retrieval of methane in all clear conditions, yielding an homogeneous long time record of tropospheric methane.

As seen on Figs. 1 and 2, infrared $\mathrm{CH}_{4}$ sensitive channels are also essentially sensitive to temperature. Hence, the simultaneous use of IASI infrared measurements, sensitive to both temperature and $\mathrm{CH}_{4}$ variations, and of AMSU microwave measurements, only sensitive to temperature, allows separating these two effects. AMSU channels 6 and 7 will be used in the retrieval procedure since their temperature weighting functions, shown in Fig. 2d, are the closest to those of the selected IASI channels, with no sensitivity to the surface.

\subsection{A non-linear inference scheme}

The weakness of the signal induced on IASI brightness temperature (BT) by $\mathrm{CH}_{4}$ variations, associated with the complexity (in particular its non-Gaussianity) of the relationship between $\mathrm{CH}_{4}$ concentration and observed BT, makes it difficult to solve this inverse problem. Therefore, a nonlinear inference method, based on the Multilayer Perceptron (MLP) neural network (Rumelhart et al., 1986) with two hidden layers, has been preferred to a more classical one. This method has already been used to derive tropospheric $\mathrm{CO}_{2}$ integrated content from TOVS (Chédin et al., 2003, 2008), AIRS (Crevoisier et al., 2004) and IASI (Crevoisier et al., 

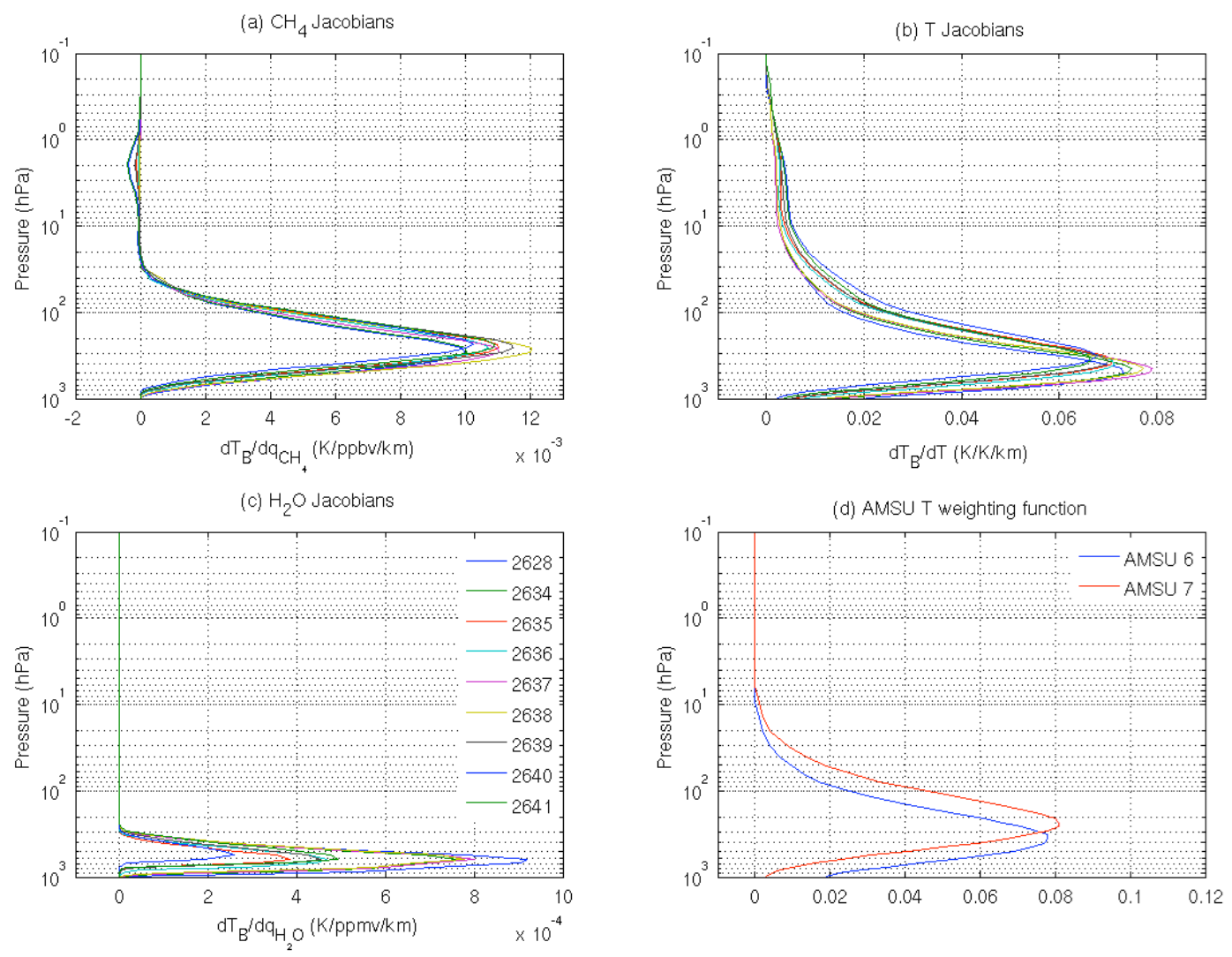

Fig. 2. $\mathrm{CH}_{4}$ (a), temperature (b) and $\mathrm{H}_{2} \mathrm{O}$ (c) Jacobians of the 9 IASI channels selected to estimate methane, and (d) temperature weighting functions of AMSU channels 6 and 7 (average over the TIGR tropical atmospheric situations).

2009). A detailed description of the method can be found in these references.

The chosen neural architecture is the following. The input layer is composed of: (1) the 9 IASI BT of the tropospheric channels given in Table 1, (2) 2 AMSU BT of channels 6 and 7 , and (3) 2 differences between IASI and AMSU BT, to help constrain the convergence process. All together, there are 13 predictors. The output layer of the network is composed of: (1) the difference between the 'true' value of $\mathrm{CH}_{4}$ concentration (associated with inputs) and the 'reference' one (1860 ppbv), and (2) 9 differences between the 'true' IASI BT (associated with the true $\mathrm{CH}_{4}$ concentration value) and the 'reference' one (associated with the reference $\mathrm{CH}_{4}$ concentration value), once again to constrain the solution. All together, there are 10 predictands. To increase the signal to noise ratio, and speed the learning phase, we have chosen to divide the infrared noise by 2 . This requires using the average of the 4 IASI BT contained in each single AMSU field-of-view as inputs to the networks. Hence, retrievals are performed at the AMSU spatial resolution.

The TIGR database (see Sect. 2.2) is used as the training set from which the networks learn the relationship existing between inputs and outputs. Network input BT correspond to randomly drawn values of $\mathrm{CH}_{4}$ concentration in the range 1700-1900 ppbv and are computed from the reference value in TIGR using the $\mathrm{CH}_{4}$ Jacobians. It is worth noting that no prior information is thus given to the networks in terms of seasonality, trend, or geographical patterns of methane.

Our past experience and several trials have led us to choose 70 neurons for the first hidden layer and 40 for the second one. Use is made of the Error Back-Propagation learning algorithm (Rumelhart et al., 1986), with stochastic steepest descent. At each step of the learning phase, the instrument noise is taken into account by adding to the BT of each channel a random Gaussian noise characterized by the equivalent noise temperature $(N E \Delta T)$ computed at the BT of the channel, according to Eq. (1). A total of 7 MLPs have been trained, one for each of the first seven AMSU local zenithal angle, ranging from nadir to an upper limit of $40^{\circ}$ to avoid the edges of the orbits.

As stated before, IASI channels are mostly sensitive to tropospheric variations of methane. The averaging kernels, which indicate which part of the atmosphere the retrievals are representative of, are determined through radiative transfer simulations based on the TIGR atmospheric profiles not used in the training of the neural networks. A uniform 
Table 1. List of IASI channels selected to retrieve methane. Columns 3 to 8 indicate the sensitivity (in K) of each channel to the variation of $\mathrm{CH}_{4}(10 \%), \mathrm{H}_{2} \mathrm{O}(20 \%), \mathrm{N}_{2} \mathrm{O}(2 \%)$, atmospheric temperature $(1 \mathrm{~K})$, surface temperature $(1 \mathrm{~K})$ and surface emissivity $(0.01)$. Column 10 gives the pressure $P_{\max }$ of the maximum of the $\mathrm{CH}_{4}$ Jacobians.

\begin{tabular}{cccccccccc}
\hline Channel & $\begin{array}{c}v \\
\left(\mathrm{~cm}^{-1}\right)\end{array}$ & $\begin{array}{c}\mathrm{CH}_{4} \\
(\mathrm{~K})\end{array}$ & $\begin{array}{c}\mathrm{H}_{2} \mathrm{O} \\
(\mathrm{K})\end{array}$ & $\begin{array}{c}\mathrm{N}_{2} \mathrm{O} \\
(\mathrm{K})\end{array}$ & $\begin{array}{c}\mathrm{T} \\
(\mathrm{K})\end{array}$ & $\begin{array}{c}\mathrm{T}_{\text {surf }} \\
(\mathrm{K})\end{array}$ & $\begin{array}{c}\epsilon_{\text {surf }} \\
(\mathrm{K})\end{array}$ & $\begin{array}{c}\text { Noise } \\
(\mathrm{K})\end{array}$ & $\begin{array}{c}P_{\max } \\
(\mathrm{hPa})\end{array}$ \\
\hline 2628 & 1301.75 & 1.07 & 0.13 & 0.09 & 0.92 & 0.01 & 0.03 & 0.20 & 292 \\
2634 & 1303.25 & 1.06 & 0.11 & 0.08 & 0.94 & 0.01 & 0.02 & 0.21 & 292 \\
2635 & 1303.50 & 1.13 & 0.06 & 0.05 & 0.97 & 0.00 & 0.00 & 0.24 & 262 \\
2636 & 1303.75 & 1.11 & 0.07 & 0.06 & 0.98 & 0.00 & 0.00 & 0.23 & 262 \\
2637 & 1304.00 & 1.17 & 0.12 & 0.07 & 0.97 & 0.01 & 0.02 & 0.20 & 292 \\
2638 & 1304.25 & 1.27 & 0.11 & 0.05 & 0.96 & 0.00 & 0.01 & 0.21 & 262 \\
2639 & 1304.50 & 1.18 & 0.07 & 0.04 & 0.96 & 0.00 & 0.01 & 0.24 & 262 \\
2640 & 1304.75 & 1.00 & 0.05 & 0.05 & 0.97 & 0.00 & 0.00 & 0.27 & 235 \\
2641 & 1305.00 & 1.08 & 0.08 & 0.04 & 0.95 & 0.00 & 0.00 & 0.25 & 235 \\
\hline
\end{tabular}

perturbation of $\mathrm{CH}_{4}$ mixing ratio is applied sequentially to each of the 40 layers of the atmospheric profiles. IASI and AMSU brightness temperatures are then computed for each of the perturbed atmospheric profiles and used as inputs of the neural network. The theoretical change $F_{i}$ in ppmv/ppmv of the column mean apparent mixing ratio $(\hat{q})$ given a mixing ratio perturbation of $\Delta q^{\text {ref }}$ at level $i$, is then given by

$F_{i}=\frac{\hat{q}\left(\Delta q_{i}=\Delta q^{\mathrm{ref}}\right)-\hat{q}\left(\Delta q_{i}=0\right)}{\Delta q^{\mathrm{ref}}}$

The mean and standard deviation of the averaging kernel for the IASI $\mathrm{CH}_{4}$ retrieval is plotted in Fig. 3. In the tropics, the height of the tropopause is approximately $17 \mathrm{~km}$. Thus, the non linear inference scheme described above gives access to a mid-to-upper tropospheric integrated content of $\mathrm{CH}_{4}$ covering the range $100-500 \mathrm{hPa}$ (roughly $5-15 \mathrm{~km}$ ), with the highest sensitivity around $230 \mathrm{hPa}$.

\subsection{Radiative bias removal}

The MLPs are trained with simulated data. Therefore, before presenting observations to the networks, potential radiative systematic biases existing between simulations and observations must be removed. For each channel, the bias is obtained by averaging, over the first year of operation (July 2007August 2008) and over the whole tropics $\left(20^{\circ} \mathrm{S}: 20^{\circ} \mathrm{N}\right)$, the differences between simulations, based on the forward model used and radiosonde measurements from the ECMWF ERA40 database, and collocated (in time and space) satellite observations.

\section{Results and discussion}

AMSU channel 6 is modestly, though significantly, sensitive to surface, and particularly to relief. Hence, performing the retrievals over land would require a more detailed study of the influence of surface elevation: so far, the present application is limited to sea cases. Based on the non-linear inference scheme described in Sect. 3, 16 months, from July 2007 to October 2008, of coupled IASI and AMSU observations have been interpreted in terms of a tropospheric integrated content of $\mathrm{CH}_{4}$ in the tropical belt $\left(20^{\circ} \mathrm{N}: 20^{\circ} \mathrm{S}\right)$, over sea, at night, for clear-sky only. Cloud detection scheme is based on a succession of several multispectral threshold tests, described in Crevoisier et al. (2009).

\subsection{Potential perturbations of the retrievals}

Through the careful selection described in Sect. 3.1, IASI channels used in the estimation process have a reduced sensitivity to water vapor. It is nonetheless required to verify that the neural networks have successfully been able to decorrelate $\mathrm{CH}_{4}$ from water vapor. Similarly, the separation between temperature and $\mathrm{CH}_{4}$ through the use of simultaneous infrared and microwave observations has to be validated. To perform this analysis, we use IASI Level2 temperature and water vapor products (see Sect. 2.1), which have the advantage of being estimated directly from IASI: they thus describe precisely the state of the atmosphere at the locations we estimate $\mathrm{CH}_{4}$. The coefficient of linearity $R$ between our estimates of tropospheric $\mathrm{CH}_{4}$ and either IASI Level 2 temperature at $200 \mathrm{hPa}$ (maximum of IASI $\mathrm{CH}_{4}$ averaging kernel plotted in Fig. 3) or water vapor contained in the troposphere (between 100 and $500 \mathrm{hPa}$ ) are 0.00 and 0.10 , respectively. Both products are totally decorrelated; there is no remaining contamination of $\mathrm{CH}_{4}$ retrievals from neither atmospheric temperature nor water vapor.

\subsection{Seasonal cycles}

Figure 4 shows the monthly zonal average of IASI $\mathrm{CH}_{4}$ retrievals for 8 latitudinal bands of $5^{\circ}$ each from $20^{\circ} \mathrm{N}$ to $20^{\circ} \mathrm{S}$, over the Pacific Ocean. Since contrary to $\mathrm{CO}_{2}$ 


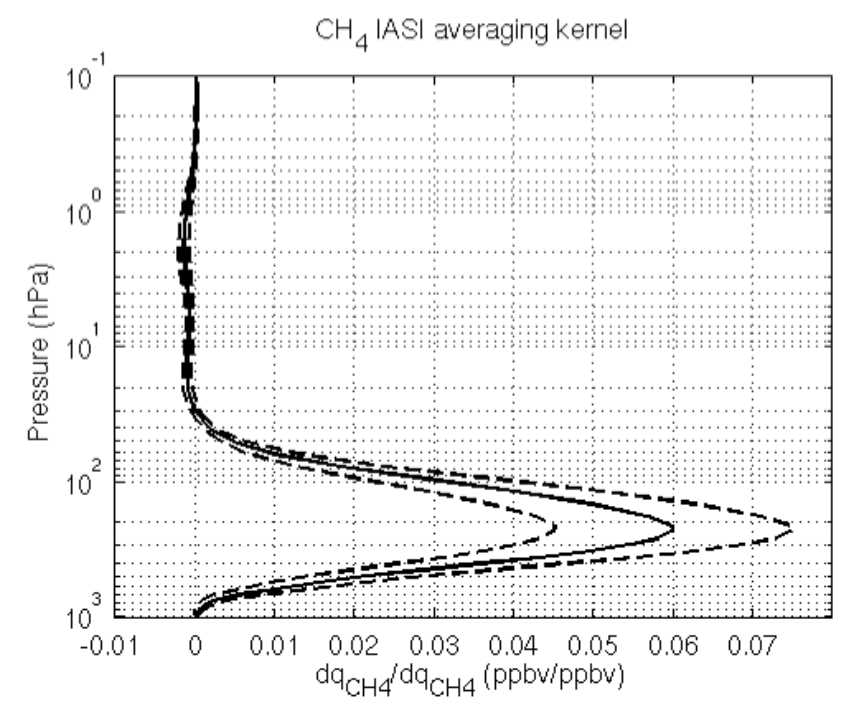

Fig. 3. Averaging kernel of $\mathrm{CH}_{4}$ IASI retrieval. Mean (full line) plus or minus standard deviation (dashed lines) over the TIGR tropical atmospheric situations.

and $\mathrm{CO}$, no regular aircraft measurement of methane is available in the tropics, only measurements of methane made at the surface can be used to evaluate these results. Few sites are available in this region. They provide some information on the expected seasonality and latitudinal variation of methane, which is a combination of various seasonal phenomena: sources (wetlands, termites, biomass burnings, anthropogenic), sinks (chemical destruction by $\mathrm{OH}$ ), and atmospheric transport. Figure 5 shows the monthly evolution of $\mathrm{CH}_{4}$ measured at 5 stations from the GLOBALVIEW-CH $\mathrm{CH}_{4}(2008)$ network: $\mathrm{MLO}\left(19.53^{\circ} \mathrm{N}\right.$, $\left.155.57^{\circ} \mathrm{W}, 3.4 \mathrm{~km}\right), \operatorname{KUM}\left(19.52^{\circ} \mathrm{N}, 154.82^{\circ} \mathrm{W}, 3 \mathrm{~m}\right)$, GMI $\left(13.43^{\circ} \mathrm{N}, 144.78^{\circ} \mathrm{E}, 2 \mathrm{~m}\right)$, CHR $\left(1.70^{\circ} \mathrm{N}, 157.17^{\circ} \mathrm{W}, 3 \mathrm{~m}\right)$, and SMO $\left(14.24^{\circ} \mathrm{S}, 170.57^{\circ} \mathrm{W}, 42 \mathrm{~m}\right)$, for the period July 2004-December 2007.

Both the IASI retrievals and the surface measurements show a strong North-to-South gradient. In the northern tropics, the seasonality retrieved from IASI is in agreement with in-situ observations: a strong seasonal cycle is observed, with a minimum in April-July and a maximum in November-February. However, the decrease of methane starts earlier on the retrieved IASI cycle (March) than at the surface (April to June, depending on the year). The amplitude of the IASI cycle, representative of the mid-toupper troposphere, is about $40 \mathrm{ppbv}$, lower than the amplitude observed at the surface by about $20 \mathrm{ppbv}$. In the $5^{\circ} \mathrm{N}$ EQ band, the global variation of IASI methane agrees well with what is observed at $\mathrm{CHR}\left(1.7^{\circ} \mathrm{N}\right)$. The early decrease in $\mathrm{CH}_{4}$ from February to April retrieved by IASI is also sometimes observed at CHR, as in 2006. After almost a decade of constant globally-averaged atmospheric methane abundance

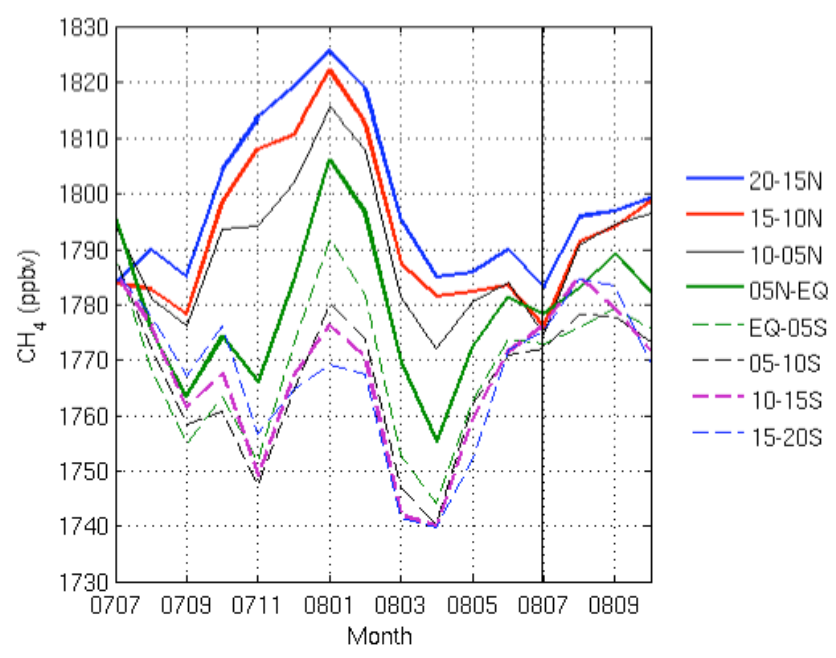

Fig. 4. Seasonal cycle of methane as retrieved in the mid-to-upper troposphere from IASI over the Pacific Ocean in 8 latitudinal bands of $5^{\circ}$ each from July 2007 to October 2008 .

(Dlugokencky et al., 2003), a renewed global growth of about 10 ppbv year $^{-1}$ is observed at all stations since the beginning of 2007 (Rigby et al., 2008). Such an increase is also retrieved by IASI as seen from comparing the months of JulySeptember 2007 and the same months in 2008. A longer period is however required to confirm this tendency.

In the Southern tropics, no clear seasonal cycle is retrieved from IASI. This is in agreement with the relatively weak seasonal cycle observed in-situ. A peak of $20 \mathrm{ppbv}$ as compared to previous and following months is observed by IASI in January-February 2008 South of $10^{\circ} \mathrm{S}$. This feature is also seen in 2006 at SMO. However, these two months correspond to a rather high inter-annual variability observed at SMO for the period January to March. For instance, the seasonal cycles observed at SMO in the southern hemisphere and at the other sites in the northern tropics tend to be negatively correlated in 2005 (minimum of methane in boreal winter at SMO and maximum at the northern stations) but positively correlated in 2006-2007 (maximum of methane in JanuaryFebruary in both the northern and southern tropics). This particular feature seems to be due to year-to-year fluctuations in interhemispheric transport during January-March, which tends to cancel the summer minimum, mainly due to photochemical destruction of methane (Dlugokencky et al., 1994), observed in the southern hemisphere at higher latitude (Prinn et al., 1992).

According to Figs. 4 and 5, the North-to-South latitudinal variation of methane retrieved from IASI is lower than the one observed at the surface. To evaluate this result, we use measurements of methane performed by aircraft in the troposphere at $11 \mathrm{~km}$ (thus close to the maximum of IASI averaging kernel plotted in Fig. 3), over the Pacific, between 


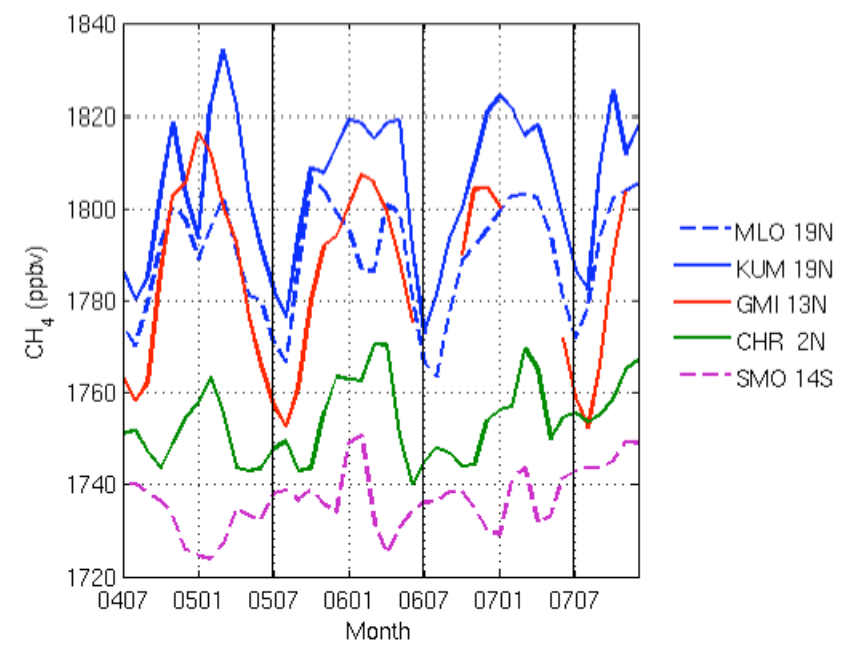

Fig. 5. Seasonal cycle of methane measured at the surface at 5 sites from July 2004 to December 2007.

April and September 1993 (Matsueda and Inoue, 1996). The latitudinal variations of methane, averaged over the period April to September, as observed by IASI in 2008 and by the aircraft in 1993 are plotted in Fig. 6 (for comparison purposes, IASI values have been adjusted to the 1993 methane average). Tropospheric methane observed by IASI increases from the South to the North by about 30 ppbv. This is in excellent agreement with the aircraft measurements. From the five stations used above, the same latitudinal variation is observed at the surface, but with much larger amplitude (about $70 \mathrm{ppbv}$ ), highlighting the proximity of emissions and vertical mixing. As observed on both Figs. 4 and 6, methane is well-mixed in the southern tropics while a gradient persists with methane regularly increasing with latitude in the northern tropics.

\subsection{Geographic distribution}

Maps of seasonal mean $\mathrm{CH}_{4}$ concentration are shown in Fig. 7 from September 2007 to August 2008, at a spatial resolution of $5^{\circ} \times 5^{\circ}\left(1^{\circ} \times 1^{\circ}\right.$ moving average $)$. This resolution was chosen to average enough individual retrievals to make robust statistics. After the removal of not-clear observations, the number of individual retrievals, per month and per $5^{\circ} \times 5^{\circ}$ gridbox, is about 400 in regions where clear-sky is prevailing but can be as low as 10 in more cloudy areas. To eliminate possible undetected clouds, boxes having less than 40 individual retrievals are not considered (blank areas on Fig. 7). They mostly correspond to regions of deep convection with persistent cloudiness.

To compare this satellite product to MOZART-2 simulations, it is necessary to properly take into account the vertical weighting function $F_{i}$ of the retrieval algorithm given by Eq. (2) in ppmv/ppmv. Since a given variation of the

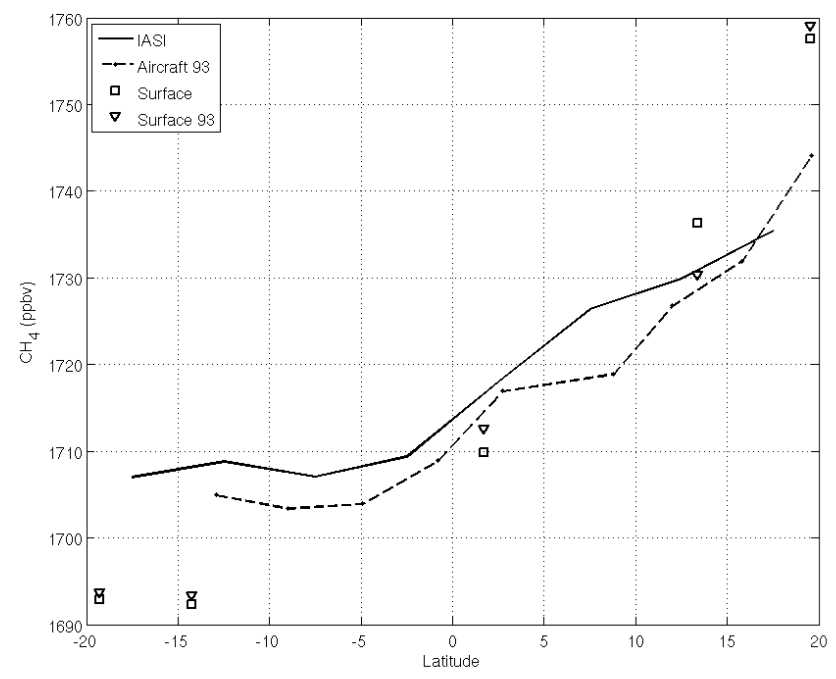

Fig. 6. Latitudinal variation of methane as retrieved in the mid troposphere from IASI (full line), as observed at $11 \mathrm{~km}$ by aircraft in 1993 (dashed line with circles), as observed at the surface in 20032006 (squares) and as observed at the surface in 1993 (triangles). For the sake of comparison, all curves have been adjusted to match the aircraft 1993 mean.

mixing ratio in two pressure layers with different thicknesses does not imply the same variation of molecules in each layer, translating $F_{i}$ to the vertical discretization of MOZART-2 requires normalizing the function by the TIGR layer thickness $\Delta P_{i}$ on which $F_{i}$ has been computed. This results in the molecular weighting function $G_{i}$

$G_{i}=\frac{\sum_{i=1}^{N} \Delta P_{i}}{\Delta P_{i}} F_{i}$

where $N$ is equal to 40 , the number of TIGR pressure layers. The $40 G_{i}$ values are independent of the layer thickness and they can be interpolated to any vertical layer distribution. Note that they are normalized so that the sum of the $G_{i}$, weighted by layer pressure thickness, is 1 . The simulated integrated content of $\mathrm{CH}_{4}$, denoted $q_{\mathrm{CH}_{4}}^{\mathrm{MOZ}}$, is finally given by

$q_{\mathrm{CH}_{4}}^{\mathrm{MOZ}}=\frac{\sum_{i=1}^{M} H_{i} \Delta p_{i} q_{i}}{\sum_{i=1}^{M} H_{i} \Delta p_{i}}$

where $H_{i}$ is the vertical weithing function $G_{i}$ interpolated on the $M$ pressure layers $\Delta p_{i}$ used by MOZART-2. Figure 8 shows the resulting integrated content of $\mathrm{CH}_{4}$, averaged over 2000-2004, as simulated by MOZART-2, driven by NCEP winds and using the surface fluxes described in Sect. 2.3 as boundary conditions.

Overall, there is a good agreement between IASI and MOZART geographical patterns. However, the range of variation of IASI $\mathrm{CH}_{4}$ is larger by about $20 \mathrm{ppbv}$, and the comparison of Figs. 7 and 8 shows a positive difference between 

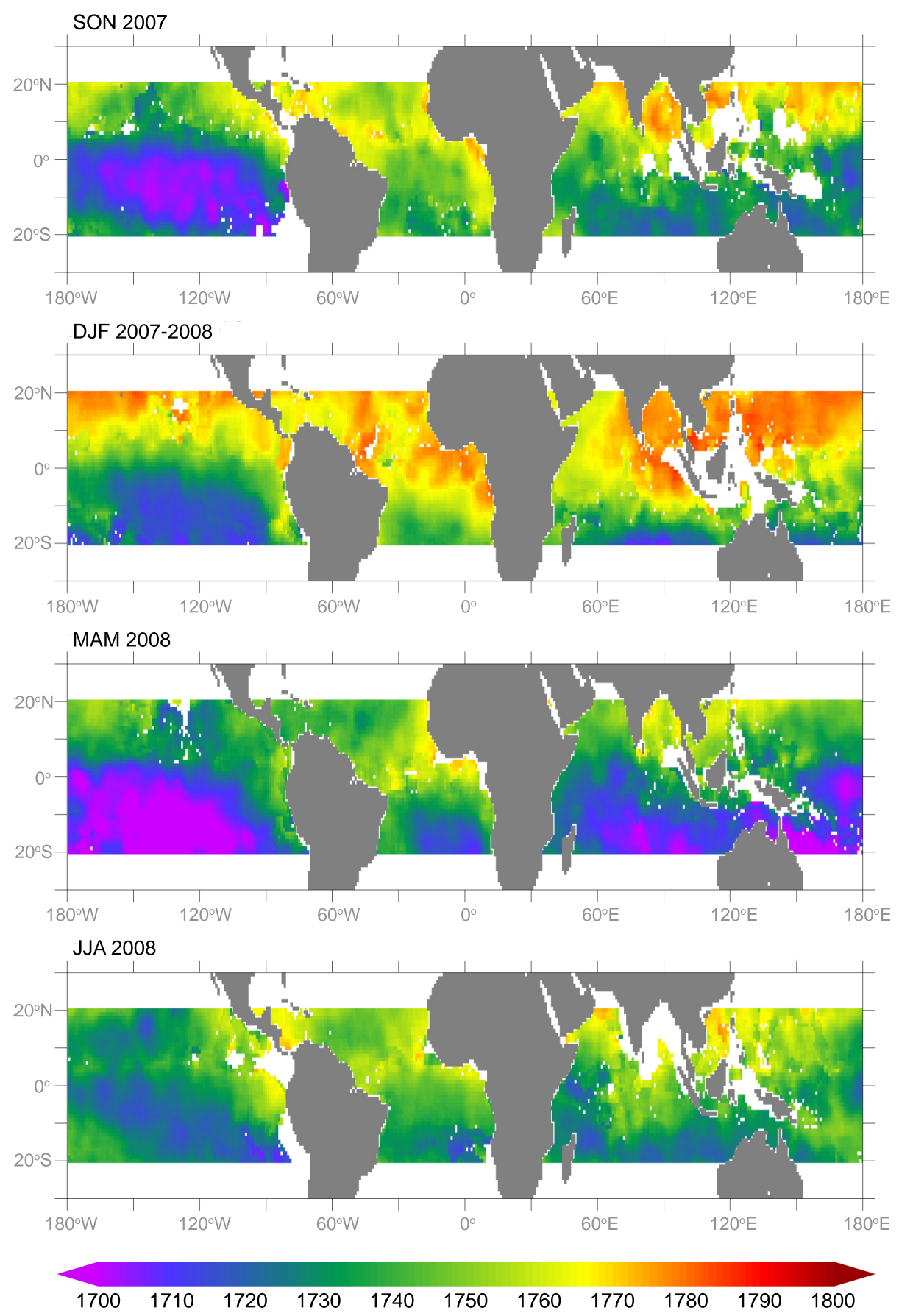

Fig. 7. Seasonal mid-to-upper tropospheric integrated content of methane (ppbv) as retrieved from IASI observations, from September 2007 to August 2008, at a resolution of $5^{\circ} \times 5^{\circ}$.

retrieved and simulated methane. This result is in agreement with several studies based on satellite (Bergamaschi et al., 2007; Meirink et al., 2008) or aircraft measurements in the tropics (Miller et al., 2007), which have indicated significantly larger tropical emissions than previously reported. According to IASI, and in agreement with aircraft measure- ments performed at MLO, the magnitude of the simulated $\mathrm{CH}_{4}$ is too low by about 20 ppbv. This might be caused either by biases in the emission inventories used to perform the simulations, or by too weak convection in the model, a known limitation of atmospheric transport models (e.g., Stephens et al., 2007). 

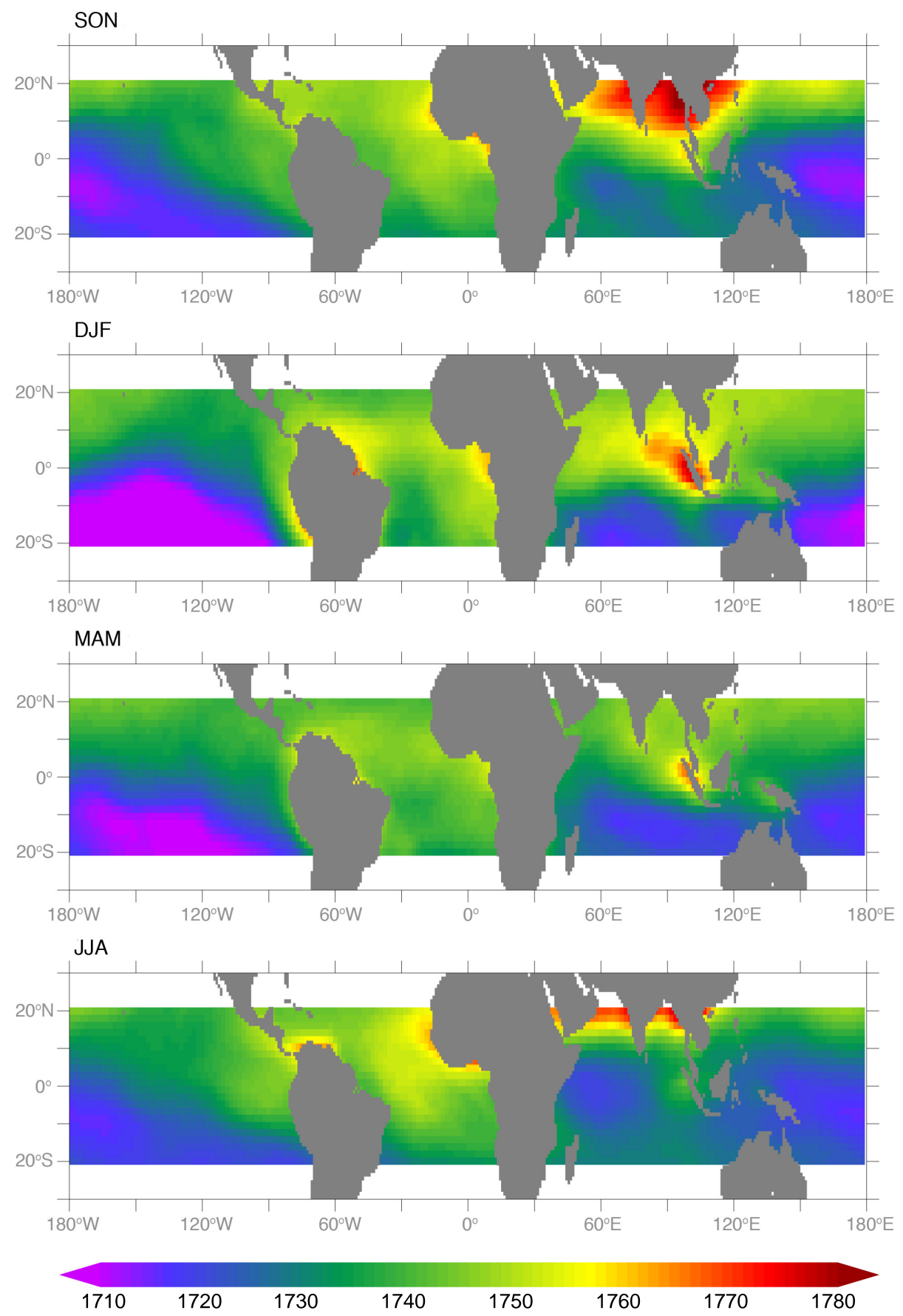

Fig. 8. Seasonal mid-to-upper tropospheric integrated content of methane (ppbv) as simulated by MOZART-2 and averaged over 2000-2004.

General patterns observed by IASI, and simulated by MOZART-2, include a year-long low $\mathrm{CH}_{4}$ region over most of the Pacific ocean, plumes of elevated $\mathrm{CH}_{4}$ between Africa and South America, year-long high values over Asia and the adjacent oceanic basins, and a latitudinal and temporal variation in agreement with in-situ observations. Also seen on the simulations, a plume of $\mathrm{CH}_{4}$ can be observed originating from Central and northern South America from August to September, where very large methane emissions have been retrieved by SCIAMACHY (Frankenberg et al., 2005). However, the signal observed by IASI, and simulated by MOZART-2, is more consistent with the lower values of the revised version of SCIAMACHY results (Frankenberg et al., 2008). 
Plumes of methane retrieved west of Africa show a latitudinal variation with the season. According to IASI, in boreal winter, methane is transported out of Africa towards the Atlantic Ocean mainly through the coast of central Africa $\left(10^{\circ} \mathrm{N}: 10^{\circ} \mathrm{S}\right)$, which might indicate large emissions of $\mathrm{CH}_{4}$ from this region; in boreal summer, methane exits from West Africa $\left(5^{\circ} \mathrm{N}: 15^{\circ} \mathrm{N}\right)$. This time-latitude variation is in agreement with the seasonality of methane emissions from African wetlands (Bergamaschi et al., 2007).

A particularly strong signal is the large plume of $\mathrm{CH}_{4}$ retrieved south of the Asian continent from October to April, which agrees very well with model simulations and with retrievals from AIRS observations (Xiong et al., 2009). This large plume, which originates south of the Tibetan Plateau during the Asian summer monsoon, which is also the period of high emissions from rice paddies (Huang et al., 2004), seems to get first transported in the troposphere by deep convection and then tends to go South to reach Indonesia. Unfortunately, the persistent cloudiness over the Asian continent from July to September precludes IASI from seeing the beginning of the plume. In boreal winter, emissions become stronger over Indonesia. Comparisons between MOZART2 simulations and IASI retrievals show that IASI observes a much larger dispersion of the plume over the nearby oceanic basins. This might explain part of the peak of $\mathrm{CH}_{4}$ seen on the seasonal variation in the southern tropics plotted in Fig. 5. The high values of $\mathrm{CH}_{4}$ retrieved by IASI in boreal winter may also be explained by transport of air with elevated $\mathrm{CH}_{4}$ from the northern hemisphere where methane emissions are at their maximum.

In the absence of observed global maps of tropospheric $\mathrm{CH}_{4}$, a first way of quantifying the dispersion of the retrievals is to determine the standard deviation of each monthly $5^{\circ} \times 5^{\circ}$ box item sample. A small dispersion of $19 \mathrm{ppbv}$ is observed (less than $1 \%$ of the mean $\mathrm{CH}_{4}$ mixing ratio), which partly comes from the errors due to the method and to the instrument, and partly from the natural variability of methane within each box over one month. The smallest values of the standard deviation $(\sim 17 \mathrm{ppbv})$ correspond to the months of July-September) when the natural variability (and the concentration, in particular in the northern tropics) is at its minimum, and the maximum values ( $\sim 21 \mathrm{ppbv})$ correspond to the months of January-March when the natural variability (and the concentration, in particular in the northern tropics) is at its maximum. Following Chédin et al. (2003), these standard deviations may tentatively be seen as resulting from the combination of the standard deviation of the method $\left(\sigma_{M}\right)$ itself and of the standard deviation of the natural variability $\left(\sigma_{V}\right)$ of $\mathrm{CH}_{4}\left(5^{\circ} \times 5^{\circ}\right.$, one month). Doing so, $\sigma_{M}$ comes to about $16 \mathrm{ppbv}(\sim 0.9 \%)$ and $\sigma_{V}$ comes to 5 ppbv in July-September and to $14 \mathrm{ppbv}$ in January-March. Such numbers look reasonable. However, this result is more an appreciation of the internal consistency of the method than an estimation of its accuracy.
Associated with the comparison to in-situ measurements and atmospheric transport model simulations, these values bring some confidence in the overall description of the features of the $\mathrm{CH}_{4}$ field variability. More detailed analysis of the results and comparisons with other satellite data will be the subject of a follow-on paper.

\section{Conclusions}

With its high spectral resolution and low radiometric noise, IASI provides new capabilities to monitor methane in the troposphere. Nine channels, located in band $v_{4}$ of methane near $7.7 \mu \mathrm{m}$, present high sensitivities to methane, reduced sensitivities to water vapor, and no sensitivity to nitrous oxide and surface characteristics. They are mostly sensitive to methane variations in the mid-to-upper troposphere, thus leading to the retrieval of a mid-to-upper tropospheric integrated content representative of the $5-15 \mathrm{~km}$ range in the tropics through the use of a non-linear inference scheme based on neural networks. The retrievals, performed for clear-sky only, agree well with in-situ measurements in terms of seasonality, annual increase and latitudinal variation. Comparisons with simulations from an atmospheric transport and chemistry model give confidence in the ability of IASI to detect the geographical distribution of tropospheric methane. Retrievals over land and at higher latitude is currently under development.

It is worth noting that the $\mathrm{IASI} \mathrm{CH}_{4}$ retrieval scheme does not use any a priori information on the trend, the seasonality, nor the geographical distribution of methane. Likewise, the IASI $\mathrm{CH}_{4}$ retrievals are fully independent from any a priori knowledge of the state of the atmosphere and do not rely on any Level 2 data. It has been demonstrated that the method has fully decorrelated methane from water vapor and temperature variations. This has been achieved by using observations performed simultaneously by IASI, sensitive to both temperature and methane, and AMSU, only sensitive to temperature. The performance of the retrieval is thus linked to both IASI and AMSU instruments. The precision of the retrieval has been found to be about $16 \mathrm{ppbv}(\sim 0.9 \%)$, for a $5^{\circ} \times 5^{\circ}$ spatial resolution on a monthly time scale. However, validation in the upper troposphere is challenging due to lack of direct measurements.

As illustrated by the detection of a plume of elevated methane in the late summer over the Pacific, which can be attributed to Asian emissions uplifted to the troposphere, IASI retrievals present a means to detect atmospheric transport pathways and, together with high resolution methane aircraft-based observations in the upper tropical troposphere (e.g. Richard et al., 2006), to improve our knowledge on the mechanisms that transport methane emissions from the surface to the upper atmosphere. While not sensitive to surface methane, IASI observations might thus prove useful for constraining atmospheric transport in a so-called surface flux 
inversion. The retrievals being only performed in clear-sky conditions, it is however needed to take this into account while performing any estimate of sources and sinks. With the launch of two other successive IASI-like instruments, scheduled for 2011 and 2015, more than 20 years of methane will be available for climate studies.

Acknowledgements. This work has been supported in part by the European Community under the contract FP6-516099 ("GEMS"). We particularly wish to thank C. Boone and the Ether team for their help in getting IASI data, as well as the two anonymous referees for their comments and suggestions. We gratefully acknowledge G. Dufour for fruitful discussions. IASI has been developed and built under the responsibility of the Centre National d'Etudes Spatiales (CNES, France). It is flown onboard the Metop satellites as part of the EUMETSAT Polar System. The IASI L1 data are received through the EUMETCast near real time data distribution service.

\section{Edited by: A. Richter}

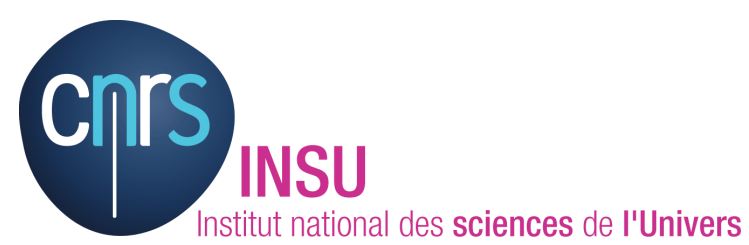

The publication of this article is financed by CNRS-INSU.

\section{References}

Bergamaschi, P., Frankenberg, C., Meirink, J. F., Krol, M., Dentener, F., Wagner, T., Platt, U., Kaplan, J. O., Körner, S., Heimann, M., Dlugokencky, E. J., and Goede, A.: Satellite chartography of atmospheric methane from SCIAMACHY on board ENVISAT: 2. Evaluation based on inverse model simulations, J. Geophys. Res., 112, D02304, doi:10.1029/2006JD007268, 2007. Bousquet, P., Ciais, P., Miller, J. B., Dlugokencky, E. J., Hauglustaine, D. A., Prigent, C., Van der Werf, G. R., Peylin, P., Brunke, E.-G., Carouge, C., Langenfelds, R. L., Lathière, J., Papa, F., Ramonet, M., Schmidt, M., Steele, L. P., Tyler, S. C., and White, J.: Contribution of anthropogenic and natural sources to atmospheric methane variability, Nature, 443(7110), 439-443, 2006.

Buchwitz, M., de Beek, R., Noël, S., Burrows, J. P., Bovensmann, H., Schneising, O., Khlystova, I., Bruns, M., Bremer, H., Bergamaschi, P., Körner, S., and Heimann, M.: Atmospheric carbon gases retrieved from SCIAMACHY by WFM-DOAS: version $0.5 \mathrm{CO}$ and $\mathrm{CH}_{4}$ and impact of calibration improvements on $\mathrm{CO}_{2}$ retrieval, Atmos. Chem. Phys., 6, 2727-2751, 2006, http://www.atmos-chem-phys.net/6/2727/2006/.

Chédin, A., Scott, N. A., Wahiche, C., and Moulinier, P.: The improved initialisation inversion method: A high resolution physical method for temperature retrievals from satellites of the TIROS-N series, J. Clim. Appl. Meteorol., 24, 128-143, 1985.

Chédin, A., Serrar, S., Scott, N. A., Crevoisier, C., and Armante, R.: First global measurement of mid-tropospheric $\mathrm{CO}_{2}$ from NOAA polar satellites: Tropical zone, J. Geophys. Res., 108(D18), 4581, doi:10.1029/2003JD003439, 2003.

Chédin A., Scott, N. A., Armante, R., Pierangelo, C., Crevoisier, C., Fossé, O., and Ciais, P.: A quantitative link between $\mathrm{CO}_{2}$ emissions from tropical vegetation fires and the daily tropospheric excess (DTE) of $\mathrm{CO}_{2}$ seen by NOAA-10 (1987-1991), J. Geophys. Res., 113, D05302, doi:10.1029/2007JD008576, 2008.

Chen, Y.-H. and Prinn, R. G.: Estimation of atmospheric methane emissions between 1996 and 2001 using a three-dimensional global chemical transport model, J. Geophys. Res., 111, D10306, doi:10.1029/2005JD006058, 2006.

Chevallier, F., Chéruy, F., Scott, N. A., and Chédin, A.: A neural network approach for a fast and accurate computation of a longwave radiative budget, J. Appl. Meteorol., 37, 1385-1397, 1998.

Cicerone R. J. and Oremland, R. S.: Biogeochemical aspects of atmospheric methane, Global Biogeochem. Cy., 2, 299-237, 1988.

Clerbaux, C., Hadji-Lazaro, J., Turquety, S., Mégie, G., and Coheur, P.-F.: Trace gas measurements from infrared satellite for chemistry and climate applications, Atmos. Chem. Phys., 3, 14951508, 2003, http://www.atmos-chem-phys.net/3/1495/2003/.

Crevoisier, C., Chédin, A., and Scott, N. A.: AIRS channel selection for $\mathrm{CO}_{2}$ and other trace-gas retrievals, Q. J. Roy. Meteor. Soc., 129, 2719-2740, 2003.

Crevoisier, C., Heilliette, S., Chédin, A., Serrar, S., Armante, R., and Scott, N. A.: Midtropospheric $\mathrm{CO}_{2}$ concentration retrieval from AIRS observations in the tropics, Geophys. Res. Lett., 31, L17106, doi:10.1029/2004GL020141, 2004.

Crevoisier, C., Chédin, A., Matsueda, H., Machida, T., Armante, R., and Scott, N. A.: First year of upper tropospheric integrated content of $\mathrm{CO}_{2}$ from IASI hyperspectral infrared observations, Atmos. Chem. Phys., 9, 4797-4810, 2009, http://www.atmos-chem-phys.net/9/4797/2009/.

Dlugokencky, E. J., Steele, L. P., Lang, P. M., and Masarie, K. A.: The growth rate and distribution of atmospheric methane, J. Geophys. Res., 99(D8), 17021-17043, 1994.

Dlugokencky, E. J., Houweling, S., Bruhwiler, L., Masarie, K. A., Lang, P. M., Miller, J. B., and Tans, P. P.: Atmospheric methane levels off: Temporary pause or a new steady-state?, Geophys. Res. Lett., 30(19), 1992, doi:10.1029/2003GL018126, 2003.

Fiore, A. M., Horowitz, L. W., Dlugokencky, E. J., and West, J.: Impact of Meteorology and Emissions on Methane Trends, 1990-2004, Geophys. Res. Lett., 33, L12809, doi:10.1029/2006GL026199, 2006.

Frankenberg, C., Meirink, J. F., van Weele, M., Platt, U., and Wagner, T.: Assessing methane emissions from global space-borne observations, Science, 308, 1010-1014, doi:10.1126/science.1106644, 2005.

Frankenberg, C., Meirink, J. F., Bergamaschi, P., Goede, A. P. H., Heimann, M., Körner, S., Platt, U., VanWeele, M., and Wagner, T.: Satellite chartography of atmospheric methane from SCIAMACHYon board ENVISAT: Analysis of the years 2003 and 2004, J. Geophys. Res., 111, D07303, doi:10.1029/2005JD006235, 2006.

Frankenberg, C., Bergamaschi, P., Butz, A., Houweling, S., Meirink, J. F., Notholt, L., Petersen, A. K., Schrijver, H., Warneke, T., and Aben, I.: Tropical methane emissions: A revised view from SCIAMACHY onboard ENVISAT, Geophys. Res. Lett., 35, L15811, doi:10.1029/2008GL034300, 2008. 
GLOBALVIEW-CH 4 : Cooperative Atmospheric Data Integration Project - Methane, CD-ROM, NOAA ESRL, Boulder, Colorado (also available on Internet via anonymous FTP ftp://ftp.cmdl. noaa.gov/, Path: ccg/ch4/GLOBALVIEW), 2008.

Horowitz, L. W., Walters, S., Mauzerall, D. L., Emmons, L. K., Rasch, P. J., Granier, C., Tie, X., Lamarque, J.-F., Schultz, M. G., Orlando, G. S. T. J. J., and Brasseur, G. P. : A global simulation of tropospheric ozone and related tracers: Description and evaluation of MOZART, version 2, J. Geophys. Res., 108(D24), 4784, doi:10.1029/2002JD002853, 2003.

Houweling, S., Kaminski, T., Dentener, F., Lelieveld, J., and Heimann, M.: Inverse modeling of methane sources and sinks using the adjoint of a global transport model, J. Geophys. Res., 104(D21), 26137-26160, 1999.

Huang, Y., Zhang, W., Zheng, X. H., Li, J., and Yu, Y. Q.: Modeling methane emission from rice paddies with various agricultural practices, J. Geophys. Res.-Atmos., 109, D08113, doi:10.1029/2003JD004401, 2004.

IPCC: Climate Change 2007: The Physical Science Basis, in: Contribution of Working Group I to the Fourth Assessment Report of the Intergovernmental Panel on Climate Change, edited by: Solomon, S., Qin, D., Manning, M., Chen, Z., Marquis, M., Averyt, K. B., Tignor, M., and Miller, H. L., Cambridge University Press, Cambridge, United Kingdom and New York, NY, USA, 996 pp., 2007.

Jacquinet-Husson, N., Scott, N. A., Chédin, A., Crépeau, L., Armante, R., Capelle, V., and 47 co-authors: The GEISA spectroscopic database: Current and future archive for Earth and planetary atmosphere studies, J. Quant. Spectrosc. Ra., 109, 10431059, 2008.

Logan, J. A., Prather, M. J., Wofsy, S. C., and McElroy, M. B.: Tropospheric chemistry: a global perspective, J. Geophys. Res., 86, 7210-7254, 1981.

Matsueda, H. and Inoue, H. Y.: Measurements of atmospheric $\mathrm{CO}_{2}$ and $\mathrm{CH}_{4}$ using a commercial airliner from 1993 to 1994, Atmos. Environ., 30, 1647-1655, 1996.

Matthews, E. and Fung, I.: Methane emissions from natural wetlands: Global distribution, area, and ecology of sources, Global Biogeochem. Cy., 1, 61-86, 1987.

Meirink, J. F., Bergamaschi, P., and Krol, M. C.: Four-dimensional variational data assimilation for inverse modelling of atmospheric methane emissions: method and comparison with synthesis inversion, Atmos. Chem. Phys., 8, 6341-6353, 2008, http://www.atmos-chem-phys.net/8/6341/2008/.

Mikaloff-Fletcher, S. E., Tans, P. P., Bruhwiler, L. M., Miller, J. B., and Heimann, M.: $\mathrm{CH}_{4}$ sources estimated from atmospheric observations of $\mathrm{CH}_{4}$ and its ${ }^{13} \mathrm{C} /{ }^{12} \mathrm{C}$ isotopic ratios: 1 . Inverse modeling of source processes, Global Biogeochem. Сy., 18, GB4004, doi:10.1029/2004GB002223, 2004a.

Mikaloff-Fletcher, S. E., Tans, P. P., Bruhwiler, L. M., Miller, J. B., and Heimann, M.: $\mathrm{CH}_{4}$ sources estimated from atmospheric observations of $\mathrm{CH}_{4}$ and its ${ }^{13} \mathrm{C} /{ }^{12} \mathrm{C}$ isotopic ratios: 2. Inverse modeling of $\mathrm{CH}_{4}$ fluxes from geographical regions, Global Biogeochem. Cy., 18, GB4004, doi:10.1029/2004GB002224, 2004b.

Miller, J., Gatti, L., d'Amelio, M., Crotwell, A., Dlugokencky, E., Bakwin, P., Artaxo, P., and Tans, P. P.: Airborne measurements indicate large methane emissions from the eastern Amazon basin, Geophys. Res. Lett., 34, L10809, doi:10.1029/2006GL029213,
2007.

Niro, F., Jucks, K., Hartmann, J.-M.: Spectra calculations in central and wing regions of $\mathrm{CO}_{2}$ IR bands. IV: Software and database for the computation of atmospheric spectra, J. Quant. Spectrosc. Ra., 95, 469-481, 2005.

Olivier, J. G. J. and Berdowski, J. J. M.: Global emissions sources and sinks, in: The Climate System, edited by: Berdowski, J., Guicherit, R., and Heij, B. J., 33-78, A. A. Balkema, Brookfield, Vt, 2001.

Olivier, J. G. J., Aardenne van, J. A., Dentener, F. J., Pagliari, V., Ganzeveld, L. N., and Peters, J. A. H. W.: Recent trends in global greenhouse gas emissions: Regional trends and spatial distribution of key sources, in: Non- $\mathrm{CO}_{2}$ Greenhouse Gases (NCGG4), edited by: van Amstel, A., 325-330, Millpress, Rotterdam, Netherlands, 2005.

Park, J. H., Russell, J. M., Gordley, L. L., Drayson, S. R., Benner, D. C., McInerney, J. M., Gunson, M. R., Toon, G. C., Sen, B., Blavier, J.-F., Webster, C. R., Zipf, E. C., Erdman, P., Schmidt, U., and Schiller, C.: Validation of Halogen Occultation Experiment $\mathrm{CH}_{4}$ measurements from the UARS, J. Geophys. Res., 101(D6), 10183-10204, 1996.

Pougatchev, N., August, T., Calbet, X., Hultberg, T., Oduleye, O., Schlüssel, P., Stiller, B., Germain, K. S., and Bingham, G.: IASI temperature and water vapor retrievals - error assessment and validation, Atmos. Chem. Phys. Discuss., 9, 7971-7989, 2009, http://www.atmos-chem-phys-discuss.net/9/7971/2009/.

Prentice, I. C., Farquhar, G. D., Fasham, M. J. R., Goulden, M. L., Heimann, M., Jaramillo, V. J., Keshgi, H. S., LeQuéré, C., Scholes, R. J., and Wallace, D. W. R.: IPCC, WGI Third Assessment Report, Cambridge: Cambridge University Press, 2001.

Prinn, R., Cunnold, D., Simmonds, P., Alyea, F., Boldi, R., Crawford, A., Fraser, P., Gutzler, D., Hartley, D., Rosen, R., and Rasmussen, R.: Global Average Concentration and Trend for Hydroxyl Radicals Deduced From ALE/GAGE Trichloroethane (Methyl Chloroform) Data for 1978-1990, J. Geophys. Res., 97(D2), 2445-2461, 1992.

Randel, W. J., Wu, F., Russell III, J. M., Roche A., and Waters, J. W.: Seasonal cycles and QBO variations in stratospheric $\mathrm{CH}_{4}$ and $\mathrm{H}_{2} \mathrm{O}$ observed in UARS HALOE data, J. Atmos. Sci., 55, 163-185, 1998.

Rayner, P. J. and O'Brien, D. M.: The utility of remotely sensed $\mathrm{CO}_{2}$ concentration data in surface source inversions, Geophys. Res. Lett., 28(1), 175-178, 2001.

Razavi, A., Clerbaux, C., Wespes, C., Clarisse, L., Hurtmans, D., Payan, S., Camy-Peyret, C., and Coheur, P. F.: Characterization of methane retrievals from the IASI space-borne sounder, Atmos. Chem. Phys. Discuss., 9, 7615-7643, 2009,

http://www.atmos-chem-phys-discuss.net/9/7615/2009/.

Richard, E. C., Tuck, A. F., Aikin, K. C., Kelly, K. K., Herman, R. L., Troy, R. F., Hovde, S. J., Rosenlof, K. H., Thompson, T. L., and Ray, E. A.: High-resolution profiles of $\mathrm{CH}_{4}$, $\mathrm{O}_{3}$, and water vapor near tropical Central America in late January to early February 2004, J. Geophys. Res., 111, D13304, doi:10.1029/2005JD006513, 2006.

Rigby, M., Prinn, R. G., Fraser, P. J., Simmonds, P. G., Langenfelds, R. L., Huang, J., Cunnold, D. M., Steele, L. P., Krummel, P. B., Weiss, R. F., O'Doherty, S., Salameh, P. K., Wang, H. J., Harth, C. M., Mühle, J., and Porter, L. W.: Renewed growth of atmospheric methane, Geophys. Res. Lett., 35, 
L22805, doi:10.1029/2008GL036037, 2008.

Rumelhart, D. E., Hinton, G. E., and Williams, R. J.: Learning internal representations by error propagation, in: Parallel Distributed Processing: Explorations in the Macrostructure of Cognition, vol. 1, edited by: Rumelhart, D. E. and McClelland, J. L., 318-362, MIT Press, Cambridge, Mass, 1986.

Schoeberl, M. R., Luo, M., and Rosenfield, J. E.: An analysis of the Antarctic Halogen Occultation Experiment trace gas observations, J. Geophys. Res., 100, 5159-5172, 1995.

Scott, N. A. and Chédin, A.: A fast line-by-line method for atmospheric absorption computations: The Automatized Atmospheric Absorption Atlas, J. Appl. Meteorol., 20, 556-564, 1981.

Spivakovsky, C. M., Logan, J. A., Montzka, S. A., Balkanski, Y. J., Foreman-Fowler, M., Jones, D. B. A., Horowitz, L. W., Fusco, A. C., Brenninkmeijer, C. A. M., Prather, M. J., Wofsy, S. C., and McElroy, M. B.: Three-dimensional climatological distribution of tropospheric OH: Update and evaluation, J. Geophys. Res., 105(D7), 8931-8980, doi:10.1029/1999JD901006, 2000.
Stephens, B. B., Gurney, K. R., Tans, P. P., Sweeney, C., Peters, W., Bruhwiler, L., Ciais, P., Ramonet, M., Bousquet, P., Nakazawa, T., Aoki, S., Machida, T., Inoue, G., Vinnichenko, N., Lloyd, J., Jordan, A., Heimann, M., Shibistova, O., Langenfelds, R. L., Steele, L. P., Francey, R. J., and Denning, A. S.: Weak northern and strong tropical land carbon uptake from vertical profiles of atmospheric $\mathrm{CO}_{2}$, Science, 316, 1732-1735, doi:10.1126/science.1137004, 2007

Wang, J. S., Logan, J. A., McElroy, M. B., Duncan, B. N., Megretskaia, I. A., and Yantosca, R. M.: A 3-D model analysis of the slowdown and interannual variability in the methane growth rate from 1988 to 1997, Global Biogeochem. Cy., 18, GB3011, doi:10.1029/2003GB002180, 2004.

Xiong, X., Barnet, C. D., Maddy, E., Sweeney, C., Liu, X., Zhou, L., and Goldberg, M.: Characterization and Validation of Methane Products from the Atmospheric Infrared Sounder (AIRS), J. Geophys. Res., 113, G00A01, doi:10.1029/2007JG000500, 2008.

Xiong, X., Houweling, S., Wei, J., Maddy, E., Sun, F., and Barnet, C.: Methane plume over south Asia during the monsoon season: satellite observation and model simulation, Atmos. Chem. Phys., 9, 783-794, 2009,

http://www.atmos-chem-phys.net/9/783/2009/. 